\title{
The Implementation of the LMKN Decree Number: 20160512rkbd/LMKN- Plenary/Tarifroyalty/2016 in Terms of Payments Managed by Cafes in Sura- baya Thorugh The Karya Cipta Indonesia Foundation at the East Java Re- gional Representative Office
}

\author{
Gempita Gloria Karunia El Shaddai*, Sri Maharani MTVM \\ Universitas Pembangunan Nasional “Veteran” Jawa Timur
}

*Corresponding author:

E-mail:

gempitagloriakes@gmail.com

\begin{abstract}
This study aimed to figure out the implementation of the LMKN Decree Number: 20160512RKBD/LMKN-Plenary/TariffRoyalty/2016 in terms of payments managed by cafes in Surabaya through the Karya Cipta Indonesia Foundation at the East Java Regional Representative Office. This research used juridical empirical methods, namely law research by taking a direct approach to the reality and legal facts that exist in the community. The juridical empirical approach is carried out by observing the objects directly, then analyzing problems that occur in society to obtain the legal fact that is used to support the research and use of the law. The results of research at the Karya Cipta Indonesia Foundation for the East Java Regional Representative Office and cafes' manager in Surabaya regarding the implementation of the LMKN Decree Number: 20160512RKBD/LMKN-Plenary/TarifRoyalti/2016 is that the payment has been made and implemented following the LMKN Decree Number: 20160512RKBD/LMKN-Plenary/TarifRoyalti/2016. However, many cafe managers do not make royalty payments and ignore the existence of the LMKN decree caused by several factors. The implementation of the LMKN decree number: 20160512RKBD/LMKN-Plenary/TarifRoyalti/2016 has met several challenges both internally and externally.

Keywords: Royalty, Copyright, LMKN
\end{abstract}

Keywords: Royalty, copyright, LMKN

\section{Introduction}

Since 2001, the world has entered a new economic era called the creative economy era. The creative economy era is an economic concept in a new economic era that emphasizes information and creativity, namely by increasing ideas and knowledge from human resources, as a production factor. the most important. This concept explains that creativity, ideas, and human ideas are the main assets in driving the economy in a country. The very diverse forms of human creativity are different from the previous era which was only limited to the nature of entertainment but developed with other new characteristics, one of which is commercial traits that can be traded. Art, one of which is music or song has become an inherent thing in human life. it is often used as a medium to convey a sense in which it presents a lot of good memories, whether it is harmonious, and gives a pleasant, entertaining feeling, or a moment that offers a unique opportunity to reflect (Smiers, 2009). If we see this, we should give an award or appreciation to the creator or author of the music or song. The appreciation as a form of appreciation can be in the form of two things, namely appreciation in terms of morale and material. can be in the form of wages or money as payment. The awarding of this award can certainly increase the enthusiasm of a music or song creator so that 
he can continue to work and create new things for the advancement of the creator's career and the personal economy and the country.

The existence of music does have a positive impact on humans. Music can also be played anywhere, including in cafes. Cafes are a place for someone or together to gather. Listening to songs, while enjoying the available drinks and food can provide calm and happiness itself, so that almost All cafes around the world play songs and music as a form of service to their visitors. This is what is called the use of music for commercial purposes and therefore a royalty collection must be held as a form of appreciation for its creators. Article 9 paragraph (1) of Law Number 28 of 2014 concerning Copyright states that one of the creators or holders of copyright economic rights is to demonstrate their creativity. For example, as a songwriter, the author has the economic right to perform his work, in this case, to distribute the song to get the results or economic value of his work. Likewise, if someone else is playing the song at a certain place or time for commercial purposes, the composer of the song is entitled to a share in the form of royalty payments as a form of his economic right. This means that if a cafe plays a song, the cafe is required or obliged to pay royalties to the creator or copyright owner of the song being played as a form of concern for the creator's economic rights.

Royalty is the amount paid for the use of creation, one of which is music for commercial purposes. The collection of royalties as stated in Article 87 paragraph (1) of Law Number 28 of 2014 concerning Copyright is the authority of LMK. LMK is tasked with collecting and managing royalties to then be distributed to the creator or related rights owner. The amount of royalty collected has been determined and stated in the Decree of the LMKN Number: 20160512RKBD / LMKNPlenary / Tariff of Royalties / 2016. In reality, although the amount of royalties has been determined and it is explained in the law that the playback of songs or music must be levied as a form of economic rights for creators and copyright owners, there are still many parties who do not make royalty payments because they do not know the rules applies so that there is no fulfillment of the appropriate rights for the author, especially in the case of royalties.

\section{Material and Methods}

This research is scientific research that is carried out with certain methods to see how the law works in society. The type of research used by the author is Juridical-Empirical. In connection with the type of empirical juridical research, the approach used is a quantitative legal approach which refers to the reality or actual situation that occurs in society. From the facts that occur in society, the author can identify these problems and then find solutions and solutions to problems (Ali, 2017). Empirical research is research conducted by examining directly from the source or related to the main source of problems in the form of interviews, polls from individuals or groups (people), or observations of objects, events, or test results (objects) consists of primary legal materials, secondary legal materials, and tertiary legal materials (Ali, 2017). These materials are arranged then reviewed and conclusions are drawn about the relationship with the problem under study.

\section{Results and Discussion}

Royalty is the service fee paid. Someone will get money if that person does something meritorious or performs a service. The copyright law itself provides an understanding of royalties as outlined in article 1 paragraph (21), namely royalty is a reward for the use of the Economic Right of a Work or Related Rights Product received by the creator or the owner of the related rights.

Royalties in the music sector are divided into 2 types, namely:

a. Royalty (royalty payment) is a payment system or compensation that is given in stages, either with or without advance payment for the use of a work. This type of payment follows the turnover from sales continuously as long as the product is sold and circulated in the market. 
b. Flat (flat payment) is a payment system directly or not in stages. In other words, royalties are paid directly or at the same time for the use of music copyright. This type of payment must be determined in the amount and period of circulation.

Royalty management in Indonesia according to Article 1 paragraph (22) is managed by an institution called the Collective Management Institute (LMK), which is an institution in the form of a non-profit legal entity authorized by the Author, Copyright Holder, and/or Related Rights owner to manage their economic rights in the form of collect and distribute royalties. The Collective Management Institute is a royalty collection agency, which distributes the money to composers, lyricists, and publishers. This money distribution activity is poured out through agreements between similar royalty collection organizations, license agreements with users and exploitation contracts, and regulations for distribution with members and their colleagues in each institution. One of the LMK collects and distributing royalties is the Karya Cipta Indonesia Foundation. Cafe managers who have registered with the Karya Cipta Indonesia Foundation can pay the royalties through the LMK.

Royalty payments are a form of insightful appreciation for their work. The creator is entitled to receive appreciation in the form of income. The income is obtained from exploiting his work. The author has the right to exploit his work because the creator has economic rights to his work. Including if other people use the work for commercial purposes, the creator has the right to withdraw royalties. This also applies to songs or music. For example, if a person or party plays a copyrighted work in the form of a song for commercial purposes such as playing a song in his cafe, this action can be classified as using creation for commercial purposes, then there is a royalty fee entitled. This is strengthened by the rules outlined in the Decree of the LMKN Number: 20160512 / LMKN-Plenary / Tariff Royaklti / 2016 in Article 1 Paragraph (3) of the Decree of the National Collective Management Agency regarding Royalty Rates for Restaurants, Cafes, Pubs, Bars, Bistro, Nightclubs, and Discotheques, which in essence state that businesses engaged in music culinary services are required to pay royalties according to the amount of royalty that has been determined in the decision. Royalty payment procedures, namely:

1. The cafe manager visited LMK, in this case, the Karya Cipta Indonesia Foundation, the East Java Regional Representative Office (KCI Jawa Timur).

2. The cafe comes to KCI Jawa Timur to register first as the party that pays the royalties. The registration begins with filling out the registration form along with a statement letter as the party who pays royalties through KCI East Java and becomes a member of KCI East Java which is given a stamp of Rp. 6,000.

3. After going through the registration process, KCI East Java will determine the amount of royalty. The determination of the amount of royalty is regulated in the Decree of the LMKN Number: 2016512 / LMKN-Plenary / Tariff Royaklti / 2016 on its sheet regarding royalty rates for restaurants, cafes, pubs, bars, bistros, night clubs and discotheques article 1 paragraph (4) which reads "royalty rates For the culinary business, restaurant and cafe music is determined per chair per year, provided that the creator royalty is Rp. 60,000 per chair per year and the related rights royalty is Rp. 60,000 per seat per year.

4. After the royalty rate is determined, the party paying the royalty will pay the royalty to KCI East Java, either by transfer or in cash. This payment is routinely made once a year by the party paying the East Java KCI. 
Table 1. Registration of cafes in Surabaya through the Karya Cipta Indonesia Foundation East Java Regional Representative Office is proven

\begin{tabular}{ccccc}
\hline Number & Year & New Cafe Register & $\begin{array}{c}\text { Cafe That Has } \\
\text { Paid The Royalty }\end{array}$ & $\begin{array}{c}\text { Cafe That Hasn' t Paid } \\
\text { The Royalty }\end{array}$ \\
\hline 1. & 2017 & 35 & 15 & 20 \\
2. & 2018 & 9 & 20 & 24 \\
3. & 2019 & 6 & 24 & 26 \\
\hline \multicolumn{2}{c}{ TOTAL } & 50 & & \\
\hline
\end{tabular}

The cafe is considered to be the place that will contribute the most royalties in a large amount. This is because of the number of cafes that are increasing every year and the possibility that each cafe will play music and songs every day from the opening to the closing of the cafe and so on. Therefore, it must be determined the number of royalties to be paid. LMKN Decree Number: 20160512 / LMKN-Plenary / Tarif Royaklti / 2016 on its sheet concerning royalty rates for restaurants, cafes, pubs, bars, bistros, night clubs, and discotheques Article 1 paragraph (4) stipulates that the amount of royalties calculated on one seat is IDR 60,000 per year for creator royalties and related rights royalties of IDR 60,000 per seat per year. The amount of payment will be very large too. Even though it has been determined that it is found that the amount of royalty payments is not following the stipulations of this decision because the decision making is only used as a temporary basis for determining the amount of royalty is influenced by factors, namely:

1. Based on the Decree of the LMKN Number: 20160512 / LMKN-Plenary / TarifRoyaklti / 2016.

2. Determination of royalties by the creator or related rights owner

3. Calculation of royalties by the National Collective Management Institute

The procedure for paying royalties in principle is not complicated or complex rules. But it still does not work following the purpose of issuing regulations for paying royalties. This is due to constraints such as many who argue that they do not understand the rules that playing music in cafes must pay royalties. In addition, some cafes have registered themselves and have received a determination of the number of royalties but have not paid royalties because the amount of royalties is considered inappropriate and detrimental.

Constraints in implementing the LMKN Decree Number: 20160512 / LMKN-Plenary / TarifRoyaklti / 2016 are divided into 2, namely:

1. Internal Constraints

Internal constraints come from within, namely the decision-maker itself, including institutions that are part of the LMKN such as the East Java KCI and other interested parties. The obstacles experienced include: lack of personnel from KCI East Java; lack of socialization carried out by both the East Java KCI, LMKN, and the government; the sanctions have given are not strict.

2. External Constraints

External constraints come from outside, namely from the community and cafe managers. The obstacles experienced include: the community does not know the existence of the LMKN Decree Number; 20160512 / LMKN-Plenary / TarifRoyaklti / 2016 and common people regarding royalties due to lack of socialization; lack of LMK in East Java; the cafe management community objected to the number of royalties or royalty prices so that many did not pay royalties according to maturity; lack of empathy and public awareness.

Lack of public understanding is one of the obstacles in not implementing the LMKN Decree Number; 20160512 / LMKN-Plenary / TarifRoyaklti / 2016. Other obstacles apart from these include, first, the parties mentioned in the decision, such as cafes, bars, restaurants, etc., do not know and understand that there are rules regarding song playback. Cafe managers in this case 
assume that songs can be played freely and do not require a contract or payment to do so (Interview with Mr. Hendrawan). Second, there are also cafe managers who have understood the rules regarding royalty payments but did not do so because they underestimated these rules because there was no firmness from the decision-maker regarding the sanctions that were obtained if they did not comply with these rules. Third, there are cafe managers who are aware of these rules and decisions by registering themselves through the LMK, one of which is the East Java KCI Foundation, but they are often late in making payments and even do not make payments because the policy is complicated and difficult because the royalty payment reduces revenue. of these cafes and the lack of strict sanctions in the rules and it does not have a positive impact either for the café (Interview with Ms. Michaella).

Given these constraints, efforts are needed to overcome these obstacles. Efforts that can be made include:

1. Efforts to overcome internal obstacles

Efforts that can be made to overcome internal constraints are increasing the number of personnel from KCI East Java. Increasing the number of personnel will also be able to solve other obstacles, namely the lack of socialization. Socialization should be held frequently, both face-toface and in newspapers, both online and offline. Socialization will increase the knowledge and insight of the community, especially cafe owners, regarding the importance of paying royalties and related to their collection. The socialization must be carried out by the government, LMKN, and LMK with the aim that the LMKN Decree Number: 20160512 / LMKN-Plenary / TarifRoyaklti / 2016 can run according to the stated objectives. The policies that are made must be maintained so that their implementation remains stable and appropriate. Moreover, the sanctions contained in existing decisions and policies must be carried out firmly, this is so that the people who own and manage the cafe do not underestimate the existence of decisions, especially so that they pay royalties according to what has been determined. so as not to violate the decision.

2. Efforts to overcome external obstacles

Efforts that can be made in overcoming obstacles that come from outside are by providing understanding to the public that royalties are very important and provide understanding to cafe owners about the existence of decisions. This understanding aims to make the community more empathetic and aware and not underestimate the existence of royalties. Apart from that, another effort that can be done is to increase the number of LMK in East Java. For example, out of 9 LMKs that received operational permits, there were only 2 LMKs in East Java. This amount must be added, such as by opening a new branch office in East Java. Efforts that can be made are also receiving suggestions and input from the public on matters relating to royalties, such as determining the number of royalty prices so as not to be too burdensome for the cafe manager.

The East Java KCI Foundation is one of the LMKs of the many LMKs in Indonesia. KCI East Java has carried out its duties and functions properly. until someone doesn't pay royalties. If in implementing the decision there are still obstacles such as delays in paying royalties, then KCI can impose a sanction in the form of a warning with two reprimands. A warning that has been done but does not bring results, then the next process is delegated to the creator of the relevant rights holder if the creator wants to process it legally. Efforts that can be made are to stick to their functions and responsibilities and to always ensure that royalty payments can be properly paid and distributed to the creators or copyright holders. This is because KCI Jawa Timur as LMK is the collector and distributor of royalties (Interview with Ms. Deta).

\section{Conclusion}

1. Implementation of Royalty Payments by Cafes in Surabaya through the Karya Cipta Indonesia Foundation Based on LMKN Decree Number: 20160512RKBD / LMKN-Plenary / TariffRoyalty / 2016 has been implemented by the Karya Cipta Indonesia Foundation since the decision was issued. LMKN Decree Number: 20160512 / LMKN-Plenary / 
TarifRoyaklti / 2016 is used by the Karya Cipta Indonesia Foundation as the basis for determining the number of royalties or rates and royalty payments by cafes in Surabaya. This decision is mainly applied to cafes that register themselves through the Karya Cipta Indonesia Foundation through regional representative offices in East Java. This implementation has been carried out following what is stipulated in the decision, but there are still many cafe managers who do not understand about royalties and there are often delays even when payments are not fulfilled because the amount paid is too large. The rate set in the decision is only used as the basis for determining the amount Meanwhile, what happens, in reality, is that the determination of tariffs is based on certain factors, so that the amount of the tariff is often higher than the decision.

2. Constraints to the Implementation of Royalty Payments by Cafes in Surabaya through the Karya Cipta Indonesia Foundation Based on the Decree of the LMKN Number: 20160512RKBD / LMKN-Plenary / TariffRoyalty / 2016 there are many obstacles, both internal and external. These constraints include the lack of public understanding and lack of socialization, the lack of personnel in KCI East Java and the lack of LMK in East Java, the large number of royalties and the lack of strict sanctions, and the lack of public awareness.

\section{Acknowledgment}

1. Mr.Dr. H. Sutrisno, S.H., M.Hum., As Dean of the Faculty of Law UPN "Veteran" East Java.

2. Mrs. Mas Anienda Tien F, S.H., M.H as Deputy Dean I of the Faculty of Law UPN "Veteran" East Java.

3. Mrs. Dra. Ec. NurjantiTakarini, as Deputy Dean II of the Faculty of Law UPN “Veteran” East Java.

4. Mr.Fauzul Aliwarman, S.HI., M.Hum, Deputy Dean III of the Faculty of Law, UPN "Veteran" East Java.

5. Mr. Eko Wahyudi, S.H., M.H., as the Coordinator of the Study Program of the Faculty of Law UPN "Veteran" East Java.

6. Mrs. Sri Maharani MTVM, S.H., M.H as the Supervisor both during the course and during this thesis research as well as my guardian lecturer while studying at the Faculty of Law, UPN "Veteran" East Java.

7. Mr or Mrs Lecturer Lecturer at the Faculty of Law, Universitas Pembangunan Nasional "Veteran" Surabaya who has helped a lot during this education.

8. Ladies and gentlemen of the thesis examiner team who have provided important evaluations, criticisms and suggestions for future writers.

9. Ladies and gentlemen of the administration section of the Faculty of Law, "Veteran" East Java National Development University who have made it easy for administration.

10.Author's parents who have supported and prayed for the smoothness of writing this study.

11.People who are very instrumental and accompanying the process of starting a-z.

\section{References}

Ali, Z. (2017). Legal research methods, PT. Sinar Grafika. Jakarta: Ninth Printing. Jakarta.

Interview with Mr. Hendrawan as Manager at Ijo Cafe on Saturday, March 14 2020, at 19.20 WIB at Ijo Cafe Surabaya

Interview with Ms. Deta as Secretary at the Karya Cipta Indonesia Foundation East Java Regional Representative Office on Wednesday,

April 1, 2020, at 8.45 WIB at the KCI East Java Office.

Interview with Ms. Michaella as Manager at Urban Latte Sukolilo on Saturday, 4 April 2020, at 16.15 WIB at Urban Latte Sukolilo

Law Number 13 of 2016 concerning Patents

Law Number 15 Year 2001 regarding Trademarks

Law Number 19 Year 2002 regarding Copyright

Law Number 20 of 2016 concerning Trademarks and Geographical Indications

Law Number 29 of 2000 concerning Plant Varieties 
Law Number 30 of 2000 concerning Trade Secrets

Law Number 31 Year 2000 regarding Industrial Design

LMKN Decree Number: 20160512RKBD / LMKN-Plenary / Tarifroyalti / 2016

Smiers, J. (2009). Fighting for cultural diversity in the era of globalization, arts under pressure. Yogyakarta: INSISTPress.

The 1945 Constitution of the Republic of Indonesia 